\author{
Krzysztof Skorulski* \\ Innsbruck
}

\title{
Aktualność i performatywność słowa
}

Kiedy w dzisiejszych czasach słowa ,performatywny” czy performance odmieniane są we wszystkich językach, dziedzinach i formach gramatycznych, wydaje się rzeczą oczywistą, że ludzkie słowo czegoś dokonuje. To przekonanie wydaje się powszechne: widać je w poradnikach typu Tongue $F u$ - jak walczyć językiem (Sam Horn); mocno dyskutowane są ostatnio takie problemy, jak zawarty w języku potencjał przemocy, na przykład tak zwanej hate speech - „mowie nienawiści” - z dość nieporadnymi czy wręcz absurdalnymi próbami skodyfikowania jej w prawie, gdy, mówiąc dosadnie: najczęściej zarzuca ją swemu przeciwnikowi ten, kto sam ją uprawia. Skąd jednak bierze się moc słowa, ta niszcząca i ta budująca? Co o niej decyduje? Jak ona funkcjonuje - co może, a czego nie może i kiedy? W moim wystąpieniu przeanalizuję problematykę mocy języka mówionego na podstawie takich klasyków, jak Ferdinand Ebner, John L. Austin, Emile Benveniste i Pierre Bourdieu. Być może dziwi kogoś obecność Ebnera w tym gronie, ale przekonamy się, mam nadzieję, że wiele z myśli późniejszych klasyków znajdujemy już u niego.

* Dr Krzysztof Skorulski jest kierownikiem Sekcji Badań Naukowych w Internationale Ferdinand Ebner Gesellschaft w Innsbrucku. Adres: Internationale Ferdinand Ebner Gesellschaft, Brenner-Archiv. 6020 Innsbruck, Josef-Hirn-Str. 5/10, Austria; e-mail: krzysztof. skorulski@ebner-gesellschaft.org. 


\section{Ferdinand Ebner - Słowo w jego aktualności osobowej}

„Słowo” wzięte „w osobistej aktualności jego wypowiadania” stanowi niewątpliwie podstawę Ebnerowskiego myślenia w ogóle, a szczególnie myślenia o performatywnej mocy słowa w kontekście dialogu. Dlatego też postaram się rozjaśnić to pojęcie. Na pierwszy rzut oka mamy wrażenie, że chodzi tu o coś tak banalnego jak wypowiadane w danej chwili słowo, jednak w miarę zagłębiania się w tę problematykę zaczynamy dostrzegać, że pod tym sformułowaniem kryje się dużo więcej. Aż staje się jasne, że, mówiąc w sensie ebnerowskim o aktualności słowa, poruszamy się w kierunku „podstawy wszystkich rzeczy”, a przynajmniej „fundamentu naszego życia” lub też, z innej perspektywy filozoficznej, do „tajemnicy bycia”.

\subsection{Aktualność słowa - o czym mówimy}

Zatrzymajmy się na początku przy samym określeniu ,aktualność”. Następnie zbadamy, w jakim kontekście porusza się Ebner, mówiąc o aktualności słowa i jak doszedł do tego pojęcia. To wreszcie pozwoli nam skupić się na analizie powiązania aktualności z mocą słowa.

\subsubsection{Akt i potencja, akt i aktywność}

Nie trzeba być arystotelikiem czy scholastykiem, by słysząc „aktualność" pomyśleć o przeciwstawieniu ,akt-potencja”. Aspekt ten wyczuwalny jest początkowo także u Ebnera: „«Aktualność» w egzystencji świata leży w relacji tego, co w nim egzystuje, do bycia albo niebycia"1. Mówiąc lapidarnie: to, co aktualne, ,jest", natomiast to, co nieaktualne, ,nie jest" - przynajmniej jeśli mówimy o świecie, a więc o „rzeczach”. Z czasem, szczególnie w kontekście analiz życia i egzystencji indywidualnej, stawia on na pierwszym planie inne aspekty aktualności: tu akt wiąże się z aktywnością czy też z „akcją”. Szczególnie intensywnie zajmuje się on tymi tematami w swym „idealistycznym” okresie, gdy jego tematem jest „etyka życia”, udokumentowana w książce Etyka $i$ życie. Krótko podsumowując jego stwierdzenia

${ }^{1}$ Ferdinand Ebner, „Notizen“, w: Ferdinand Ebner, Schriften, t. 2, hrsg. Franz Seyr (München: Kösel, 1963), 114. 
z tego okresu: życie na poziomie człowieka polega na aktywnej odpowiedzi na imperatyw ,żyj!”, na podejmowaniu inicjatywy, wyrażającej się w koncepcji idei ,jak żyć”"

\subsubsection{Akt i substancja}

Dialogiczna wizja człowieka z późniejszych pism Ebnera jest nadal zakorzeniona we wcześniej rozważanej problematyce życia. Duch (zawsze rozumiany dialogicznie) widziany jest jako najwyższy znany nam poziom życia, jako, mówiąc lapidarnie, najwyższy produkt ewolucji. Życie jest jednak w ruchu, wyraża się w aktywności a nie statyczności, inaczej niż sugeruje nam tak zwana „tendencja do substancjalizacji”. Na czym ona polega? Już Kant zauważył w swojej nauce o kategoriach, że (przynajmniej zachodnie) myślenie dokonuje się w ramach kategorii, między innymi kategorii substancji. To uwidacznia się też - co zauważa Ebner - w tendencji do „urzeczownikowiania”4. Ten sposób postrzegania wyświadcza nam jednak, zwłaszcza przy opisie życia, niedźwiedzią przysługę, stwarzając sztuczne problemy i zniekształcając rzeczywistość. Gdy przykładowo - jak czyni to w swym wczesnym okresie Ebner - uprawiamy etykę opartą na wartościach: nigdy nie zrozumiemy wartości, postrzegając ją jako (pasywną) substancję (co sugeruje nam pojęcie, rzeczownik ,wartość”), musimy raczej spojrzeć na nią jako na „akt wartościowania” wychodzący od podmiotu. „Aktualność” wartości przeciwstawia się więc jej substancjalności. Akt jednak rodzi pytanie o swoje pochodzenie, a więc zwraca zarazem uwagę na Ja, na podmiot, działa tym samym jako princium individuationis.

\subsubsection{Akt i proces}

$\mathrm{Z}$ tą samą problematyką życia wiąże się także i inny aspekt aktualności, ujawniający się w konfrontacji z ,procesualnością” życia. 7 października 1917 roku Ebner pisał: „Naprzeciwko procesualnego charakteru życia

${ }^{2}$ Ferdinand Ebner, Ethik und Leben - Fragmente einer Metaphysik der individuellen Existenz (Hamburg u.a.: LIT, 2013), 117.

${ }^{3}$ Ferdinand Ebner, Stowo i realności duchowe. Fragmenty pneumatologiczne (Warszawa: IFIS PAN, 2006), 55.

4 Tamże, 130. 
fizycznego stoi aktualny charakter życia duchowego. Życie fizyczne dane nam jest zawsze jako proces, duchowe jako actus"s. Według niego, życie objawia się zarówno w procesach, wiążących je z materią, jak i w aktach, świadczących o obecności w nim pierwiastka duchowego. Przykładem aktu jest ludzkie myślenie i działanie, ale nie tylko to: interwencję ducha widzi on też tam, gdzie w ramach postulowanej ewolucji - w sensie przeskoku pomiędzy z gruntu różnymi sposobami bycia, jak materia martwa i żywa istnieje nieprzezwyciężalna przepaść, niewytłumaczalna na gruncie „procesualnym":

Nie możemy pojąć „rozwoju” od zwykłego procesu wegetacji, jaki stanowi istotę życia roślin, do życia zwierzęcego, zakładającego zmysłowość i świadomość, nie możemy sprawić, by stał się do pomyślenia na sposób naukowy. Ze zwykłych procesów wzrostu w mózgu nie wynika nigdy świadomość. Tu jest „skok”. I tak samo jest nie do pomyślenia rozwój od zwierzęcia do człowieka bez przyjęcia takiego właśnie „skoku”.

Różnica między aktem a procesem ukazuje się bardzo wyraźnie w słowie. Słowo w jego aktualności, ,słowo aktualne”, o które chodzi, przynależy do aktów, nie do procesów. Choćby dlatego, że coś wypowiada i powołuje do życia coś, czego dotąd nie było.

Akt, jako że pochodzi on od ducha, wprowadza pewną nieciagłość w ciagły procesualny rozwój życia. Akt wprowadza „przedtem” i „potem” Ja i Ty, pewną granicę, historię, w odróżnieniu od ciaggle takiego samego procesu rozwoju. Także i tu widzimy akt jako principium individuationis.

\subsection{Kontekst i istota aktualności słowa u Ebnera}

Chociaż także i inni myśliciele - jak zobaczymy wkrótce - wypowiadali się podobnie odnośnie do aktualności słowa (inaczej ją nazywając), to perspektywa i zainteresowania Ebnera wydają się w tym kontekście dosyć szczególne. Takie tematy, jak duch, język (mowa) w swej aktualności, osobowość, stosunek Ja do Ty, są u Ebnera ściśle powiązane, tak że gdy mówię o jednym, mam niejako na myśli także wszystkie pozostałe. Stosunek osoby mówiącej do „zagadniętej” jest „duchową atmosferą”, w której słowo „od-

\footnotetext{
5 Ebner, „Notizen”, 152.

${ }^{6}$ Ferdinand Ebner, Wort und Liebe (Hamburg u.a.: LIT, 2015), 15.
} 
dycha i żyje"7. Wymienione pojęcia tworzą swoiste universum, w każdym $z$ nich można widzieć wejście do jednego i tego samego pomieszczenia: gdy wchodzę jednymi, wychodzę często innymi drzwiami.

Stwierdźmy przy tym jedno: głównym punktem zainteresowania Ebnera jest - podobnie jak całego kręgu ówczesnych współpracowników czasopisma Brenner - chrześcijaństwo we współczesnym świecie. Jego przemyślenia, także te dotyczące aktualności słowa, służą rozjaśnieniu tego tematu.

I tak, właściwym pytaniem, jakie należałoby wraz z Ebnerem w tym kontekście postawić, byłoby: „Co umożliwia człowiekowi kontakt z Bogiem i w jaki sposób tego dokonuje? Jaką rolę spełnia przy tym Chrystus i chrześcijaństwo?" Dopiero w dalszej kolejności pojawia się pytanie o narzędzia, które umożliwią udzielenie odpowiedzi na to pierwsze pytanie, na przykład aktualność słowa i jego „maieutyczna” lub ,generatywna” moc. Dopiero po ustaleniu tych narzędzi przychodzą analizy kultury jako takiej, języka i innych obszarów - są one analizowane pod względem tego, czy wiążą człowieka z Bogiem. Dla naszego użytku uprawnione wydaje się jednak użycie zgromadzonego instrumentarium $\mathrm{w}$ innych kontekstach, pamiętając o wiążących się z tym ograniczeniach.

Takie określenie kontekstu rozważań pomoże nam wyjaśnić, dlaczego aktualność słowa odgrywa tu tak dużą rolę i jakie jest jej miejsce. W aktualności mamy bowiem szczególne powiązanie między mową a rzeczywistością, niejako dostęp do rzeczywistości, o którą chodzi. Mimo bowiem pewnego poziomu abstrakcji dotychczasowego opisu aktualności słowa, chodzi o rzecz bardzo konkretną: wypowiedź w jej aktualności udostępnia zagadniętemu Ty mówiące Ja, a więc buduje relację międzyosobową. $\mathrm{O}$ ten właśnie skutek i wywołującą go skuteczność chodzi.

Zauważmy, że także wypowiedź „nieaktualna” zakłada ,jakieś” Ty (tak zbudowany jest czy też „na tym polega” po prostu język jako taki, że ktoś musi „zabrać głos”, „dojść do słowa” i zwracać się do kogoś innego), ale nic mu nie udostępnia. Jako przykład może posłużyć nam hasło, które widziałem napisane wielkimi literami na murze w norweskim mieście Tromsø: „Chętnie bym cię uścisnął, lecz jestem tylko tekstem”. Cała wypowiedź, jej skutek, rozmywa się niejako, gdy - tak jak tu - zanegowane zostaje Ja mówiącego. Jednak także i wypowiedź pozbawiona „aktualności”, to znaczy nieskierowana do żadnego realnego Ty i nieosiagająca połączenia między językiem a rzeczywistością, mimo wszystko zakłada pewne Ty: Ty idealne, fikcyjne, a może nawet boskie.

${ }^{7}$ Ebner, Stowo, 19. 
Mimo wielkiej ilości otaczających nas wypowiedzi „nieaktualnych”, pierwotny sens mowy leży w jej aktualności, w jej działaniu, w funkcji budowania relacji i przekazywania sensu, nie zaś w kwestionowaniu sensu i izolacji jednostek. Podobnie też pierwotne znaczenie słowa „Ja” (i „Ty”) leży w jego aktualności, obejmuje „Ja realne” i aktualne, „Ja” z wypowiedzi „Ja jestem” nie zaś Ja zsubstancjalizowane z wypowiedzi „Ja jest”. W tym sensie wypowiedź nieaktualna jest „niedziałająca” (bezskuteczna, bezowocna), w tym sensie, że nie udostępnia realnemu „Ty” realnego „Ja”.

W aktualności słowa chodzi więc o „udane” udostępnienie „realnego Ja” „realnemu Ty” i to jest kryterium „czy” aktualność w ogóle występuje, i ewentualnie miernik ,na ile” jest całkowita. Aby zaś zaistniała, potrzeba spełnienia całego szeregu warunków: „Ja” nie zostanę udostępniony „Tobie” w idei (dlatego też Ebner występuje w swym dialogicznym okresie przeciw idealizmowi, który nie ma respektu wobec Ty; co więcej, którego Ty w ogóle nie interesuje) ani w nieprawdzie (tzn. gdy moja wypowiedź nie ma pokrycia w moim Ja). Nie uda się także, gdy chcemy użyć słowa instrumentalnie, nie uwzględniając jego natury i specyfiki, na przykład negując jego początek w Bogu i starając się uczynić jego źródłem samego siebie. Jeśli słowo zostanie użyte w oderwaniu od swego początku, to może stać się narzędziem zniszczenia; używając słowa mogę kogoś zranić lub poniżyć. To prowadzi do następnego warunku skuteczności słowa według Ebnera: miłości w sensie ewangelicznym (tylko słowo powiązane z miłością osiąga swój cel), bez miłości nie przyjmę bowiem słowa Innego jako pochodzącego od jego Ty (wszyscy znamy z życia sytuacje, gdy negatywnie nastawiony do drugiego nie mogę - albo nie chcę, granica jest płynna - jego wypowiedzi zrozumieć, zawsze ją przekręcam). Podobnie można mówić o warunku wolności, rozumianej jednak nie jako zamykanie się przed innymi, lecz jako wyzwolenie z zamknięcia w samotności i wejście w relację. Podsumowując: nie uda się to przy użyciu jakiejkolwiek metody niedialogicznej („bez Ty nie ma Ja”). „Słowo w aktualności swego bycia wypowiadanym” obejmuje więc w tym sensie mówiącego, to, co wypowiadane, ale także „zagadniętego”. Ich wzajemna relacja stwarza ową ,atmosferę duchową, w której słowo oddycha i żyje", a która zostaje utożsamiona $\mathrm{z}$,hagion pneuma Nowego Testamentu"9 - przynależnej do prawdziwie Ebnerowskiego rozumienia słowa.

Oczywiście, można tu zapytać, co tak naprawdę zostaje udostępnione z Ja, skoro Inny pozostaje inny? Czy nie mamy do czynienia z ,maskaradą

\footnotetext{
8 Tamże, 19.

9 Tamże, 158.
} 
i zasłanianiem” - tak jak słowo „osoba”, łac. persona, gr. prosopon - była rozumiana pierwotnie? Czy za maską nie ukrywa się po prostu inna maska i tak w nieskończoność? Być może mamy do czynienia z maskarada, gdy chodzi o „treści o mnie”, ,atrybuty mojego Ja jako substancji”, które zostają wraz z nią ,skonstruowane” (a więc o Ja z wypowiedzi „Ja jest”), ale nie wtedy, gdy chodzi o sam fakt, że ktoś do mnie ,zagadną”, że ktoś do mnie apeluje (Levinas: „nie zabijesz mnie!”), i że jestem w stanie jego „zagadnięcie”, jego „apel” przyjąć jako taki (a więc przy Ja z wypowiedzi „Ja jestem”). To właśnie między innymi w terminologii Ebnera oznacza stwierdzenie, że człowiek „ma słowo”. Tym niemniej pewna negatywność jest tu obecna: ktoś kieruje do mnie słowo, ale na pytanie „kto?” może odpowiedzieć jedynie „Ja”, wszelkie dalsze określenia pozostaną prowizoryczne.

\subsection{Aktualność i moc słowa}

Wydaje się oczywiste, że aktualność słowa wiąże się z jego „performatywną", a więc sprawczą mocą. Aby jednak przyjrzeć się bliżej ich związkowi, przeanalizujmy teraz rodzaje aktualności i rodzaje owej mocy, tak jak je widzi Ebner.

\subsubsection{Rzeczowa i osobowa aktualność słowa}

Aktualnie wypowiadane słowo należy, według Ebnera, widzieć zarówno w jego aktualności „rzeczowej”, jak i „osobowej”, czy może lepiej „osobistej”. Dopiero to rozróżnienie pozwala nam ująć słowo w całej jego rozciąłłości. Jak stwierdza Ebner (a później także Austin), właściwością słowa jest, że z jednej strony coś stwierdza, przekazuje informacje (Austin nazywa to constative utterance), $\mathrm{z}$ drugiej strony coś sprawia (performative). Rzecza, którą u Ebnera słowo bez wątpienia „sprawia”, jest owo wspomniane udostępnienie mówiącego (Ja) zagadniętemu (Ty), a więc relacja. Te dwa aspekty słowa wyrażone zostają u Ebnera za pomocą rozróżnienia między jego charakterem „rzeczowym” a „osobowym”. „Rzeczowy” wiąże się z treściowym aspektem słowa, zaś „osobowy” z jego działaniem - relacją Ja do Ty.

Każde aktualnie wypowiedziane słowo ma swoje odniesienie rzeczowe i osobowe, w każdym z nich może być brane w „swej aktualności”. Ebner pisze 5 lipca 1920 roku: 
W czym ma słowo swą aktualność? W tym, że jest mówione i w tym, że jest mówione do kogoś, przez kogo zostaje uchwycone. W tym, że buduje stosunek Ja do Ty, tzn. stwarza lub budzi życie duchowe (w człowieku). To można powiedzieć jedynie o słowie w jego aktualności osobowej. Aktualność rzeczowa budzi obiektywne zainteresowanie (i odwrotnie, zainteresowanie to wychodzi jej, słowu w jego relacji rzeczowej [do rzeczy] naprzeciw, przez co właśnie słowo jest aktualne w sensie rzeczowym) ${ }^{10}$.

Słowo w swej relacji rzeczowej odnosi się więc do rzeczy czy sytuacji, którą dane słowo oznacza, ,budzi obiektywne zainteresowanie” nią a zarazem w swej aktualności osobowej buduje relację Ja do Ty, do którego jest wypowiadane. Prawdę słowa w jego aktualności „rzeczowej” możemy badać na sposób klasycznej teorii poznania, w sensie adequatio rem ad intellectum - odpowiedniości rzeczy i przedstawienia, rzeczy i rozumu. Jednocześnie można jednak mówić o prawdzie słowa w jego „osobowej” (osobistej) aktualności, „duchowo” (tzn. spoglądając na życie duchowe, stosunek Ja do Ty) - i badać ją pod względem, czy wypowiadane słowo znajduje ,pokrycie” w mówiącym Ja. I tak, przeciwieństwem prawdy w pierwszym przypadku będzie „błąd”, w drugim zaś „kłamstwo"11. Przy okazji widzimy, co czyni wypowiedź w obu rozumieniach słowa ,nieaktualną” - kłamstwo w sensie osobowym i błąd w sensie rzeczowym.

To rozróżnienie między aktualnością osobową (osobistą) a rzeczową można oczywiście - co Ebnera interesowało najbardziej - przenieść na stosunek do Jezusa Chrystusa i jego nauki. Aktualność rzeczowa odnosi się do treści (nawet do dogmatu można odnosić się ,aktualnie”, ale nie „osobowo”), osobowa do „życia Jezusa”, czy może lepiej „do żywego Jezusa”. Można być jednak także generalnie nastawionym wobec słowa na sposób duchowy (osobowy) albo na sposób rzeczowy. Nastawienie ,rzeczowe” koncentruje się na samym słowie, ,szerokości i głębi jego sensu”, bez spoglądania od razu, od kogo pochodzi i do kogo zostaje skierowane. Takie jest w zarysie nastawienie poetów i naukowców. Nastawienie osobowe kieruje się zaś pierwotnie na moment „duchowy”, na relację Ja do Ty, by dopiero potem badać, jakie słowo jest ,właściwe”, to znaczy prowadzi do tego celu. To jest nastawienie dialogicznie-religijne, ale taż - lapidarnie - po prostu ,życiowe”.

\footnotetext{
${ }^{10}$ Ebner, „Notizen”, 260 n.

11 Tamże, 263, 542.
} 


\subsubsection{Maieutyczna i generatywna moc słowa}

Przypomnijmy, że punktem wyjścia Ebnerowskich rozważań o słowie było słowo Jezusa, a moc, o którą chodzi, to moc „generowania” czy budzenia życia duchowego, rozumianego jako wchodzenie w relację - z człowiekiem a zarazem z Bogiem. Tak więc autentyczne słowo ludzkie łączy się ze słowem boskim. I tak, dzięki swej aktualności słowo może rozwijać w odniesieniu do życia duchowego moc „maieutyczną” albo też „generatywną” w zależności od tego, o jakie słowo chodzi, przez kogo zostaje wypowiedziane i jak zostaje ono przyjęte. Pierwszy rodzaj mocy służy jako „zwykła okazja, by dojść do bycia duchowego". Obok maieutycznej mamy jednak do czynienia z mocą generatywna, która bycie duchowe w człowieku ,ustanawia" 12 . Istniejące między nimi powiązanie jest najwyraźniej takiej natury, że idealna, bezosobowa aktualność, jaką można stwierdzić w opisanym „nastawieniu rzeczowym" wobec słowa, ma na obszarze życia duchowego moc maieutyczna, podczas gdy aktualność osobista, realna, odpowiadająca nastawieniu „osobowemu” dysponuje mocą generatywną. Krótko mówiąc, słowo może w dziedzinie ducha coś zdziałać jedynie wtedy, gdy jest aktualne.

$\mathrm{Na}$ początku przyjrzyjmy się wraz z Ebnerem słowu Jezusa. W nim obecna jest moc generatywna par excellence. Jego specyfika polega na tym, że Jezus nie tylko mówi, ale także żyje tym, co mówi - życie łączy się ze słowem w stopniu najwyższym. Ebner pisze: „Bowiem życie i słowo były w Jezusie jednym"13. W nim dokonuje się w pełni owa „Reduplikacja osobowości w słowie"14. Któż poza Jezusem mógłby w pełnej aktualności powiedzieć: „Ja jestem droga, prawdą i życiem” (J 14, 6)? Późniejsi autorzy, jak na przykład Benveniste, mówią w tym miejscu o „autorytecie”, który jest nieodzownym momentem wypowiedzi performatywnych ${ }^{15}$. Ten zaś wiąże się z jednej strony z samym jego „byciem”, z tym, że Jezus jest dla chrześcijanina zbawczym słowem Boga Ojca do człowieka. Dzięki temu może mówić $\mathrm{w}$ ten sposób. $\mathrm{Z}$ drugiej strony jednak, dodajmy, jest tak dzięki wierze w jego

${ }^{12}$ Ferdinand Ebner, „Das Wissen um Gott und der Glaube”, w: Ferdinand Ebner, Schriften, t. 1 (München: Kösel, 1963), 443.

${ }^{13}$ Ferdinand Ebner, „Versuch eines Ausblicks in die Zukunft”, w: Ferdinand Ebner, Schriften, t. 1 (München: Kösel, 1963), 742.

${ }^{14}$ Ebner, Stowo, 100.

15 Emile Benveniste, Probleme der allgemeinen Sprachwissenschaft (München: List, 1974), 303n. 
słowo. Można by powiedzieć, że autorytet ten pochodzi z jednej strony od „bycia” Jezusa, ale ostatecznie od Boga, z drugiej od przyjmującego słowo człowieka, ale ostatecznie w decydującym stopniu znowu od Boga, który wyposażył człowieka w „słowo”.

W jaki sposób człowiek może mieć udział w tej performatywnej mocy? Zjawisko to opisywane jest przede wszystkim jako "słowo prorockie” a więc znów pochodzące $\mathrm{z}$ Bożego źródła. Ebner rozróżnia przy tym między przemawianiem „,w imieniu Boga" (chociaż niemieckie wyrażenie im Auftrag Gottes można by przetłumaczyć raczej ,z Bożego rozkazu” czy polecenia) i ,za Bożym przyzwoleniem” (niem. mit Gottes Erlaubnis).

Pierwsze jest zjawiskiem raczej rzadkim i nadzwyczajnym: „Ludzie, którzy mówią i działają otwarcie z polecenia Bożego, są zjawiskiem niezwykle rzadkim i są często niezrozumiali dla samych siebie. Czy było tak z Pawłem Apostołem? Z pewnością był to przypadek Savonaroli, by nie

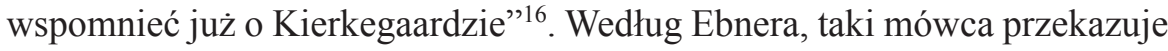
niejako „obce słowo”, które nie jest zrozumiałe dla niego samego, być może nie zgadza się też z jego życiem. On sam nie wchodzi też w relację ze swymi słuchaczami, co ukazuje się przez ów brak „,prawdziwej miłości”"17. Ten sposób mówienia, aczkolwiek możliwy, dokonuje się niejako z pogwałceniem w mówiącym tego, co ludzkie.

Mówienie „za Bożym przyzwoleniem” zdarza się częściej niż „,z Bożego polecenia”. Ebner pisze: „Kto w swojej poezji, myśleniu i życiu zbliża się do prawdy [...], ten staje się w każdej relacji o tym fakcie - zależnie od stopnia swego zbliżenia - świadomy, że to, co dane jest mu powiedzieć, zostaje powiedziane za Bożym przyzwoleniem. Jest to uszczęśliwiająca świadomość" 18 . Ebner zalicza do tej grupy pewnych pisarzy (niektórych „ludzi kultury” w sensie wyjaśnionym poniżej), ale także ludzi jak on sam, Bedenker des Wortes $^{19}$ - określenie trudne do przetłumaczenia: ,pamiętający o słowie", przechowujący słowo, przemyśliwujący słowo. Tu człowiek przemawia we własnym imieniu, a więc wypowiada „własne”, znajome słowo (nie zaś „obce”, podsunięte mu „Z zewnątrz”, dlań niezrozumiałe), ale jednak ze świadomością, że „zbliża się” do prawdy. Odczuwa tę bliskość Boga i niejako zgodność z nim, wyrażającą się w jego ,przyzwoleniu”. W tym

\footnotetext{
16 Ebner, Wort, 89.

17 Tamże.

18 Tamże.

19 Tamże.
} 
przypadku moc sprawcza słowa pochodzi niejako „z relacji” - ze zgodności słowa - mówiącego i słuchającego.

Zasugerowaliśmy powyżej związek mocy maieutycznej słowa z rzeczowym nastawieniem do niego, nastawieniem właściwym poetom i naukowcom. Tak właśnie wygląda przekazywanie performatywnej mocy słowa (w sensie przekazywania życia duchowego) poprzez kulturę. Poeta koncentruje się niejako na aktualności rzeczowej, nie interesując się od razu, kto jego słowo usłyszy. Jako że mimo wszystko musi zwracać się do jakiegoś Ty, kieruje swe słowo - mówiąc wraz z Ebnerem - do „Ty idealnego”. Inaczej mówiąc, oddaje swe słowo „kulturze”, by ta przekazywała je dalej. Ważna jest przy tym jednak ,jakość” wypowiadanego przez poetę słowa, wynikająca $\mathrm{z}$ jego pochodzenia. Jeśli jest ono autentyczne, zrodzone ze zgodności bycia ze słowem, pochodzące z relacji Ja do Ty, w przypadku poety z „,bycia zagadniętym" - ma ono z pewnością szansę, by przekazywać życie duchowe w jego aktualności. Czy tak się faktycznie stanie, zależy jednak od wielu innych czynników. Przypominam: w przypadku tego słowa chodzi o moc „maieutyczną”, o stworzenie okazji (co samo w sobie jest już dużym osiągnięciem) dojścia do życia duchowego.

Obok drogi ,,przez kulturę” jest też droga bezpośrednia, w relacji, w dia$\operatorname{logu}$, a więc, jak to formuluje Ebner, droga religii. To, co nazywa on tu religia, jest jednak w swej istocie niczym innym jak dialogiem. Chodzi tu bezpośrednio o aktualność osobową, o udostępnienie zagadniętemu Ty mojego Ja. Dodajmy, że mówiący zwraca tu się nie do jakiegoś „Ty idealnego", lecz do Ty jak najbardziej realnego, nazywanego też w tym kontekście „religijnym”. Drogę tę skojarzyliśmy z nastawieniem osobowym do słowa, wyzwalającym w nim moc ,generatywną".

Aby jednak słowo wypełniło swe zadanie przekazywania performatywnej mocy, musi być także przyjęte w swej aktualności osobistej. „Jego znaczenie dla duchowego życia człowieka leży nie w jego aktualności idealnej, lecz całkowicie w aktualności osobistej" ${ }^{20}$. Inaczej mówiąc, chodzi o to, by słowo Chrystusa brać nie jako słowo poetyckie (skierowane do „Ja idealnego", a więc do wszystkich i do nikogo), lecz jako skierowane do mnie osobiście. Dopiero tak odebrane uzyskuje „bezpośrednie odniesienie do bycia", którego brakuje słowu poetyckiemu, szczególnie do bycia samego człowieka. Wzięta jako idealna, ma owa „historyczna faktyczność życia i słowa Chrystusa” dla własnego życia duchowego znaczenie jedynie ,przy-

${ }^{20}$ Ferdinand Ebner, „Die Wirklichkeit Christi”, w: Ferdinand Ebner, Schriften, t. 1 (München: Kösel, 1963), 466. 
padkowe”, jako osobista - ,absolutne"21. Inną nazwą tego odniesienia jest „powaga”, a więc swoista „wyjątkowość”, w odróżnieniu od występującej na przykład w zabawie ,powtarzalności”. „W tym słowie, tak rozumianym, jest powaga życia duchowego, której nie ma nigdy w poecie jako takim”22. Moc słowa zależy więc od sposobu, w jaki słowo to zostaje przyjęte, $\mathrm{z}$ jaką aktualnością: jako idealne uzyskuje co najwyżej moc „maieutyczną”, ale gdy zostanie przyjęte osobiście, ma moc „generatywna”, moc „generowania” życia duchowego w człowieku. Jeszcze jedno trzeba zauważyć: moc maieutyczna, która drzemie także w słowie poety, zwracającego się do Ja idealnego, byłaby niczym bez mocy generatywnej, zawartej w słowie Chrystusa, zwracającego się do Ja realnego. Może ona jedynie ułatwić, przyśpieszyć, usunąć przeszkody na drodze do zrodzenia życia duchowego, ale nie może go „ustanowić” czy ,zrodzić” sama.

\section{Wspólczesne koncepcje performatywności}

Aby zatrzeć możliwe wrażenie, że myślenie Ebnera zamyka się w pewnej konfesyjności, warto zająć się przeniesieniem jego kryteriów na teren bardziej ogólny. Temu posłuży odwołanie się do późniejszych myślicieli, nawiązujących do podobnych tematów. Koncepcje Ebnera - wskutek niewielkiego rozpowszechnienia jego pism - nie miały co prawda bezpośredniego wpływu na dalsze rozważania o „mocy słowa”, które współcześnie koncentrują się zwłaszcza pod hasłem „performatywność”. Taki wpływ możliwy byłby co najwyżej pośrednio, poprzez oddziaływanie „filozofii dialogu” i innych dialogicznych sposobów myślenia. Podobieństwo poszczególnych dróg w dochodzeniu do wspólnych wniosków wydaje się jednak uderzające.

\subsection{John L. Austin - wypowiedź konstatywna i performatywna}

W zupełnie innym otoczeniu intelektualnym sformułował swe podejście do performatywności ten, który ukuł pojęcie Performative, John Langshaw Austin. Jako filozof języka codziennego (ordinary speech) i przedstawiciel

${ }^{21}$ Ebner, „Das Wissen”, 444.

22 Ebner, „Die Wirklichkeit”, 460. 
szkoły oxfordzkiej badał on język mówiony „w celu odsłonięcia i przezwyciężenia przesądów i procedur zasłaniających rzeczywistość" ${ }^{23}$.

Austin sprzeciwia się rządzącemu od czasów Arystotelesa obrazowi języka, w którym liczą się tylko takie zdania (wypowiedzi), które można jednoznacznie opisać jako prawdziwe lub fałszywe (w sensie adequatio). Cała reszta jest bezsensowna. Za obrazem tym kryje się odwieczne pragnienie czysto obiektywnej i pewnej wiedzy. Taka wiedza może być tylko prawdziwa lub fałszywa, innej możliwości nie ma, można ją więc zdigitalizować, a następnie budować z niej sylogizmy i całe systemy. Natomiast Austin pokazuje, że istnieją wypowiedzi, które nie są ani prawdziwe, ani fałszywe, i to nie z powodu jakiegoś zawartego w nich błędu, lecz wcale „nie chcą” i nie mają takie być. Nie można ich jednak zakwalifikować jako bezsensowne. Szczególną uwagę zwraca on przy tym na zdania, których wypowiedzenie nie jest opisem czy stwierdzeniem, lecz działaniem (np. „Przysięgam” albo „Biorę ciebie za żonę”, wypowiedziane w odpowiednich okolicznościach). Nie odnosi się do nich kryterium prawdziwości, można je jednak zakwalifikować jako „fortunne” (happy) (czy też „skuteczne”) lub „niefortunne” (infelicitous lub unhappy).

W swym dziele How to do things mit words Austin podejmuje się szczególnego zadania: najpierw wprowadza pewne uderzające odkrycie, które polega na rozróżnieniu wypowiedzi konstatywnych (constative) (opisowych) i performatywnych (performative utterance). Następnie jednak kwestionuje ten podział, stwierdzając brak jednoznacznej linii oddzielającej oba typy wypowiedzi. Każda wypowiedź ma dla niego swój aspekt performatywny i opisowy. Dodajmy, że nie wszyscy czytelnicy, jak zobaczymy w przypadku Benveniste, zrozumieli, dlaczego konieczny jest ten radykalny zwrot i pozostali przy rozróżnieniu na wypowiedzi performatywne i konstatywne.

Aby w miejsce tego pierwszego podziału wprowadzić taki, który wytrzyma krytykę, Austin cofa się od wypowiedzi do tego, czego wypowiedź jest wyrażeniem - do aktu mowy (speech act). Tak więc nie wypowiedź jest czynnikiem rozróżniającym, lecz stojący za nią ludzki akt. Austin pyta więc: „Co chcę uczynić?” i na tej podstawie rozróżnia akty. Chcę coś stwierdzić (akt lokucyjny)? Wykonać pewną społecznie określoną procedurę (np. ożenić się - akt illokucyjny)? Czy też osiagnnąć pewien efekt (np. przekonać kogoś - akt perlokucyjny)? Przy tym jest jednak oczywiste, że jeśli chcę dokonać aktu illokucyjnego, muszę jednocześnie dokonać aktu lokucyjnego.

23 Benveniste, Probleme, 297. 
Szczególnie dyskusyjnym punktem jest rozróżnianie między aktami illokucyjnymi a perlokucyjnymi. Kryterium rozróżnienia stanowi tu oczywiście sam akt (co chcę), ale jako że nie jest on widoczny na zewnątrz, dodatkowym pytaniem jest to, czy chodzi o uruchomienie jakiejś społecznie przyjętej procedury: akt illokucyjny opiera się na takowej, akt perlokucyjny nie. W tym sensie to, co początkowo określane było jako „performatyw”, staje się - w przybliżeniu - aktem illokucyjnym.

Jak brzmią jednak następujące wypowiedzi: „zawrzeć małżeństwo to wypowiedzieć kilka słów” albo „założyć się, to po prostu coś powiedzieć”24. Powstaje od razu wrażenie, że coś się tu nie zgadza. Jeśli brzmią prowokacyjnie lub paradoksalnie, to dlatego, że „moc sprawcza” leży faktycznie w niczym innym jak w słowach, ale niekoniecznie wypowiedzianych w każdej sytuacji. Niekiedy są to słowa ,puste”. Dlatego warto zapytać, kiedy słowo rozwija swą performatywną moc. Austin wymienia cały szereg warunków „fortunności” wypowiedzi, a więc warunki rozwinięcia przez nie performatywnej mocy: „Aby można było powiedzieć, że wykonaliśmy fortunnie nasze działanie, musi oprócz wypowiedzenia słów wypowiedzi performatywnej zgadzać się i odpowiednio przebiegać cały szereg innych rzeczy"25. Warunki te pogrupowane zostają w sześć kategorii:

1. - A1 - musi istnieć pewna konwencjonalna procedura;

2. - A2 - mówca musi być uprawniony do danej wypowiedzi;

3. - B1 - mówca (i inni) muszą wykonać procedurę poprawnie;

4. - B2 - i (muszą wykonać ją) całkowicie;

5. - $\Gamma 1-$ mówca musi mieć na myśli (zamierzać) to, co procedura czyni;

6. - Г2 - mówca musi działać stosownie do tego, co powiedział, czego dokona ${ }^{26}$.

Pierwsze cztery - gdy nie zostaną spełnione - powodują, że działanie jest „niebyłe”, ostatnie dwa natomiast oznaczają jedynie nadużycie (abuse) procedury ${ }^{27}$.

Moim zdaniem, Austin powołuje się przy ocenie, czy dane działanie było „fortunne”, czy nie, na pewien common sense. Widać to zwłaszcza przy dwóch ostatnich warunkach, opisujących „nadużycie”: chodzi o poczucie, że coś się nie zgadza, coś jest nieodpowiednie, niesprawiedliwe czy po prostu

${ }^{24}$ John L. Austin, Zur Theorie der Sprachakte. How to do things mit words (Stuttgart: Reclam, 1972), 30.

25 Tamże, 36.

26 Tamże, 37.

27 Tamże, 38. 
złe. Chodzi więc nie tylko o procedurę, lecz także o to dyktowane przez common sense (a może - powiedzmy otwarcie - przez moralność) poczucie.

Gdzie leży więc według Austina źródło performatywnej mocy? Z jednej strony mówi on jasno, że moc ta (dokładniej mówiąc rola illokutywna: illocutionary force) związana jest z zaakceptowaną konwencją socjalna, ale nie rozwija tego tematu, z drugiej strony stara się sporządzić listy słów, które czynią wyraźną (expicit) jego illokutywną rolę. Jego zainteresowania kierują się więc nadal na słowo języka codziennego. Możemy jednak dodać, że ogranicza się on przy tym do swego własnego języka i kultury.

\subsection{Emile Benveniste - ustanowienie podmiotowości}

Emile Benveniste, francuski lingwista, który swoimi pracami wywarł wielki wpływ nie tylko na językoznawstwo lecz także na współczesną francuską (i nie tylko) filozofię, zwrócił uwagę na Austina i szkołę oksfordzką, bowiem sam od dłuższego czasu prowadził badania na tym obszarze. Z prac Austina znał jednak tylko jego referat odnośnie do rozróżnienia między „Konstatywem a Performatywem”28 i jego zakwestionowania, w którym nie ma ani słowa o jego ,pozytywnej” teorii, o aktach mowy. Ten brak popchnął Benveniste do szukania swej własnej odpowiedzi na problem performatywności. Co ciekawe, także i ona zmierza w podobnym do Austina kierunku rozdzielenia aktu mowy od jego pozajęzykowych rezultatów (przypomnijmy: Austin dokonał tego, rozróżniając akty illokutywne od perlokutywnych).

Podczas gdy jednak Austin zwalcza - nieprecyzyjne według niego rozróżnienie między konstatywem a performatywem, dobierając przykłady pod kątem jego nieprecyzyjności, Benveniste stara się wydobyć to, co dla performatywności charakterystyczne i koncentruje się na sytuacjach, gdzie występuje ona $\mathrm{z}$ wielką wyrazistością. Zgadza się on mówić o performatywności jedynie tam, gdzie ujawnia się jej moc (np. „przysięgam!”), a nie chodzi o skostniałe formułki grzecznościowe (np. „Witam Pana!”). Dopiero w takich sytuacjach czuje się tę charakterystyczną dla wypowiedzi performatywnych dysproporcję między wyrażeniem (jego znaczeniem) a jego działaniem. W takiej wypowiedzi jak „Przysięgam!” „wypowiedź pokrywa się z działaniem. Ale warunek ten nie jest dany w znaczeniu słowa"29.

28 John L. Austin, „Performatif: constatif”, w: La Philosophie analytique (Paris: Editions de Minuit, 1962), 271-281.

${ }^{29}$ Benveniste, Probleme, 296. 
I faktycznie, kiedy koncentrujemy się na przypadkach „ekstremalnych”, zamiast na „dwuznacznych”, rozróżnienie „konstatyw-performatyw” zdaje się zachowywać swój sens.

Szczególny, a dla nas interesujący, punkt rozważań Benveniste w odróżnieniu od Austina leży w jego spojrzeniu na subiektywność (podmiotowość). Krótko mówiąc, działanie performatywne interesuje go nie tylko w sensie przeprowadzania społecznie zaakceptowanej procedury, lecz także w tym, że podmiot „ustanawia” sam siebie. Ta zdolność mówcy do tego, by ustanowić się jako podmiot, jest dla performatywności czymś rozstrzygającym:

To „podmiotowość” dyskursu czyni je [działanie] możliwym. Jest to konsekwencja faktu, że instancja dyskursu, która zawiera czasownik, stwarza działanie w tym samym momencie, w którym ustanawia podmiot. I tak, działanie zostaje dokonane poprzez instancję wypowiedzenia jego „nazwy” (np. „przysięgam"), podczas gdy jednocześnie poprzez instancję wypowiedzenia jego „indykatora” (konkretnie: ,ja”) zostaje ustanowiony podmiot ${ }^{30}$.

Całość rozważań Benveniste odnośnie do „antropologicznych aspektów” języka krąży wokół różnicy między wypowiedziami w pierwszej i drugiej, a wypowiedziami w trzeciej osobie liczby pojedynczej. Tu należy zauważyć szczególną pozycję, jaką zajmują słowa „Ja i Ty”. Nazywa się je - zauważa Benveniste - zaimkami (pronomina), ale nie są one nimi w ścisłym znaczeniu, bowiem nie zastępują żadnych ,imion" i pełnią w ramach języka zupełnie inną funkcję. Inaczej niż „On-Ona-Ono” nie wskazują na żadną klasę odniesień. Ich referencją jest zawsze pojedynczy człowiek. Nie posiadają także liczby mnogiej (zauważmy, że nasz język nie dopuszcza ,ja” w liczbie mnogiej, zaś „my” nie jest pluralizacją „Ja”, lecz opisuje według Benveniste coś zupełnie innego „Ja + Oni” albo „Ja + Wy”).

Benveniste opisuje ten szczególny status Ja i Ty bardzo dobitnie. „Te zaimki odróżniają się od wszelkich określeń, jakie wyraża język, w tym punkcie nie odsyłają ani do jakiegoś pojęcia, ani do jakiejś osoby”31. „Stoimy przed klasą słów, «zaimkami osobowymi», które umykają statutowi wszystkich innych znaków języka"32.

Kiedy ktoś (człowiek) wypowiada „Ja”, dokonuje w ten sposób czegoś: stwarza „Ja” - siebie samego - jako podmiot oraz rzeczywistość dyskursu.

\footnotetext{
30 Tamże, 296.

31 Tamże, 291.

32 Tamże, 291.
} 
Jako motto można wziąć zdanie: „«Ego» jest ten, kto mówi «Ego»”33. Dopiero w ten sposób staje się możliwa mowa: „Mowa możliwa jest tylko dlatego, że każdy mówiący ustanawia siebie jako podmiot, odnosząc się w swojej mowie do siebie samego jako Ja". Mówiący odnosi się w swej mowie do siebie samego, to właśnie umożliwia język ${ }^{34}$. Do czego odsyła więc „Ja”? Odsyła do wydarzenia indywidualnej mowy, w której zostaje wypowiedziane, i oznacza jej mówcę ${ }^{35}$.

Istotę języka można, swoją drogą, widzieć w tym, że jest w nim możliwa ta właśnie podmiotowość: język zorganizowany jest $w$ ten sposób, że pozwala on każdemu mówiącemu przyswoić sobie (przejąć) cały język przez to, że określa się jako Ja albo nawet: ,Język jest więc możliwością podmiotowości" 36 . Kiedy przyjrzymy się dokładniej jednostce dyskursu i wydarzającej się w niej „podmiotowości”, zauważymy, że przynależy do niej zawsze - także u Benveniste - nie tylko Ja, nie tylko „słowo" (to, co jest mówione), ale i Ty. I tak wracamy do Ebnerowskiego słowa w aktualności jego wypowiadania.

Rozważania Benveniste odnośnie do podmiotowości i performatywności, wynikające z lektury Austina i jego własnych badań sytuacji „wyraźnie performatywnych", możemy podsumować w jego znanych czterech charakterystykach wypowiedzi performatywnych:

1. autorytet (a więc, jak u Austina, działająca procedura i uprawnienie do jej wykonania);

2. jednorazowość (powtórzenie wypowiedzi nie powoduje jeszcze raz tego samego, to można by odnieść do Ebnerowskiej powagi);

3. autoreferencja (wypowiedź ustosunkowuje się do wytworzonej przez nią sytuacji; mówiący odnosi się do siebie samego);

4. nazwanie („Ego” - działający i jego działanie zostają jednoznacznie nazwane - tu przypomina się Ebnerowska „reduplikacja” Ja w aktualnym słowie) $)^{37}$.

Skąd więc bierze się tu moc performatywnego słowa? Ukazują się następujące możliwości: $\mathrm{z}$ autorytetu (a więc $\mathrm{w}$ ramach danej grupy), z języka, który stawia do dyspozycji określone struktury, oraz z konstytucji samego człowieka, który „przejmuje” język wypowiadając „,a”.

\footnotetext{
33 Tamże, 289

34 Tamże, 291.

35 Tamże, 291.

36 Tamże, 293.

37 Tamże, 303 n.
} 


\subsection{Pierre Bourdieu - magia społeczna}

Zainteresowanie Pierre Bourdieu performatywnością związane jest przynajmniej po części z lekturą Austina i Benveniste. Podczas gdy lingwista Benveniste interesuje się w pismach Austina językowymi cechami i podstawami performatywności, Bourdieu jako socjolog zwraca uwagę na społeczne warunki performatywności - skąd biorą się te procedury (Austin) i autorytet mówiącego na sposób performatywny (Benveniste)? Mówiąc ogólnie, performatywna moc (Bourdieu mówi przy tym raczej o „,społecznej magii”) pochodzi według niego nie z samego języka, z wypowiadania pewnych szczególnych słów, lecz od grupy społecznej, która tenże język stosuje.

Austin jedynie na marginesie zajmuje się pytaniem, jak dana procedura zostaje wprowadzona lub zmieniona. Pod tym względem rządzą u niego stabilne warunki (różnice mają miejsce ewentualnie między poszczególnymi językami). Bourdieu tematyzuje tymczasem właśnie „nazywanie” i „rytuały ustanowienia" danej procedury. Tak więc dla niego w centrum nie stoi wypowiedź: „Chrzczę ten okręt imieniem Królowej Elżbiety” (by wziąc jeden z przykładów Austina), lecz raczej jak ustanawia się procedurę „chrztu” okrętu i kto ma prawo ją przeprowadzić.

Pyta więc nie tyle o rytuał, lecz, ,jak mogę objąć funkcję potrzebną do tego, by ochrzcić okręt"? Pierwszy punkt to ,akt mianowania” (acte d'institution) czy też rytuał ustanowienia: „Ów akt społecznej magii, który polega na próbie udzielenia istnienia temu, co nazwane, może się udać, gdy temu, kto go dokonuje, uda się zdobyć uznanie [...] wobec mocy swojego słowa, mocy wprowadzenia nowego przedstawienia (vision) i nowego podziału (division) społecznego świata" 38 . Rolą rytuałów ustanowienia (np. nadających godności społeczne) jest oddzielanie: wskazują one na pewną linię, która rozdziela (w pewnych sytuacjach pozwalają ją też przekraczać), wprowadzają związane z tym rozróżnienie: na przykład okręt w budowie/w eksploatacji. „Mówienie o rytuałach ustanowienia oznacza skierowanie uwagi na to, że każdy rytuał liczy na potwierdzenie lub legitymizację, a więc na to, że dowolna granica nie wygląda na dowolną, lecz zostaje uznana za uprawnioną i naturalną"39.

${ }^{38}$ Pierre Bourdieu, Was heißt Sprechen? zur Ökonomie des sprachlichen Tausches (Wien: Braumüller, 2005), 98.

39 Tamże, 84. 
Następne logiczne pytanie: dlaczego obowiązuje właśnie ten rytuał a nie jakiś inny? Aby na nie odpowiedzieć, należy zastanowić się nad walkami o klasyfikację, nad walkami o wprowadzenie własnej wizji, często wbrew innym $^{40}$. Czym w gruncie rzeczy są walki o klasyfikację, opisuje Bourdieu następująco: „Walki klasyfikacyjne [są to], walki o monopol na władzę nad widzeniem i wiara, znajomością i uznaniem, nad uprawnioną definicją podziałów świata społecznego a przez to nad tworzeniem i (rozwiązywaniem) grup społecznych" ${ }^{41}$.

Ten, kto wygrał walkę o klasyfikację, może wprowadzić preferowany przez siebie porządek społeczny, zapewnić mu trwałość, opierającą się na pozornie realnej, ,potwierdzonej naukowo” bazie. Podstawy tego porządku nie są kwestionowane, pod tym względem panuje konsensus, pewien common sense, który - jak wspomniałem - jest punktem wyjścia dla Austina: „Jak wiadomo, porządek społeczny zawdzięcza swą trwałość [...] faktowi, że wprowadza on w życie schematy klasyfikacyjne, które [...] prowadzą do pewnej formy uznania tego porządku, a mianowicie tej, która wiąże się z zapoznaniem dowolności jej podstaw"42.

Także wypowiedzi naukowe (szczególnie nauk społecznych) są performatywne (tu w jeszcze innym sensie niż u Austina). Kiedy na przykład Karl Marx twierdzi, że istnieją dwie przeciwstawne klasy społeczne (które to stwierdzenie miało niewątpliwie charakter opisowy „stwierdzający, że są”), a jego twierdzenia zostają za pomocą pewnego znaczącego środowiska społecznego uznane i wprowadzone w czyn, to klasy te faktycznie istnieją - nie tyle ze względu na rzeczywistość społeczna, lecz ze względu na dokonaną wypowiedź. Tak jak formuła „posiedzenie jest otwarte”, także i teza ,istnieją dwie klasy" może być rozumiana jako wypowiedź stwierdzająca albo performatywna ${ }^{43}$.

Bourdieu nazywa to zjawisko „efektem teorii” ${ }^{44}$. Także i nauka nie jest w żadnym razie „obiektywnym” i „odseparowanym” (nieoddziałującym) obserwatorem niezależnej od niej rzeczywistości, lecz jak najbardziej oddziałuje na nią swoimi wypowiedziami, klasyfikacjami, pojęciami. Nauka nie jest w stanie się od tego powstrzymać, co najwyżej jedynie spróbować dostrzec swą prawdziwą rolę. To może się udać „Jeśli wyjdziemy poza

\footnotetext{
40 Tamże, 71.

${ }^{41}$ Tamże, 95.

42 Tamże, 104.

43 Tamże, 111.

44 Tamże, 110.
} 
przeciwstawienie realności i przedstawienia [...] i kiedy do tego, co realne, zaliczymy także przedstawienia realności, albo, dokładniej, walkę między przedstawieniami”" ${ }^{\prime 4}$.

Nauka jest więc - poprzez efekt teorii - w równym stopniu polityka. Widać to na przykładzie takiego słowotwórstwa (akty mianowania) jak ,,antysemityzm” albo ostatnio „homofobia”, „islamofobia”, a z drugiej strony „ideologia gender” - które sprawiają wrażenie terminów naukowych, a są faktycznie niczym innym jak narzędziami walki politycznej. Druga strona stara się je zwalczać, zaprzeczać ich istnieniu. Wprowadzenie takich terminów jest stwarzaniem, kształtowaniem rzeczywistości.

Konstruowanie faktów społecznych i politycznych ma jednak oczywiście swoje granice. Bourdieu pisze: „Skutki tej walki byłyby jednak całkowicie nie do przewidzenia, gdyby Allodoxii, fałszywemu postrzeganiu a przede wszystkim fałszywemu wyrażaniu, nie były postawione żadne granice" 46 .

A skąd pochodzi tu moc performatywnej wypowiedzi? Bourdieu uważa:

Ta illocutionary force, pozajęzykowa moc wypowiedzi, jest więc - podobnie jak w wypowiedziach performatywnych, w których jest „oznaczana”, albo lepiej, w podwójnym sensie, „reprezentowana” - nie do znalezienia w samych słowach... Moc słów jest niczym innym jak delegowaną mocą mówiącego, a jego słowa - to znaczy nierozdzielnie przedmiot jego dyskursu i jego sposób mówienia - są w każdym razie jednym z dowodów - gwarancji delegacji, którą otrzymał ${ }^{47}$.

Bourdieu zajmuje się jednak w swych rozważaniach tym, co wraz z Ebnerem nazwaliśmy „Ja idealnym”, grupa, nie zaś „Ja realnym” i dialogiem. Dla niego dialog byłby prawdopodobnie czymś opierającym się na wprowadzonej w życie klasyfikacji. Ale już na podstawie odkryć Benveniste widzimy, że istnieje istotna różnica między Ja/Ty a My, oba światy rządzą się różnymi prawami. A gdy chodzi o - sugerowany przez Bourdieu - pierwotny charakter grupy przed językiem: czy istnieją gdzieś grupy bez języka, czy bez języka możliwe jest powstanie jakiejkolwiek grupy?

\footnotetext{
45 Tamże, 95.

46 Tamże, 110.

${ }^{47}$ Tamże, 73.
} 


\section{3. Źródło mocy słowa}

Podobnie jak „chrześcijańsko-dialogiczne” podejście Ebnera pomogło wypracować pewien aparat pojęciowy przydatny także w innym kontekście, z innym punktem wyjścia, tak samo i takie podejścia jak filozoficzno-analityczne Austina, lingwistyczno-antropologiczne Benveniste czy „lewicująco-socjologiczne" Bourdieu mogą dostarczyć pewnej korekty tego aparatu czy umożliwić jego rozszerzenie.

Przypomnijmy: Ebner spogląda na sprawczą moc słowa od strony dialogu, życia duchowego, Chrystusa. Jego celem jest opuszczenie samotności Ja i nawiązanie relacji, stosunku realnego Ja do realnego Ty - Ty w człowieku, ale poprzez niego z Ty Boskim. Można by powiedzieć, że jest to pewne życzenie, pewien cel, można by powiedzieć „stan docelowy”, ludzka czy też osobowa strona słowa. Takie słowo ma swoją moc: wyzwala, buduje, rodzi czy budzi życie duchowe i prowadzi naprzód rozwój człowieka (jako indywiduum i jako gatunku).

Nie zawsze jednak doświadczamy słowa od tej właśnie strony. Nieraz słowo zamiast wyzwalać zniewala, zamiast budować uciska, zamiast otwierać zamyka. W wizji Ebnera jest to oczywiście nadużycie słowa. Czy jednak takie słowo jest zjawiskiem jednoznacznie negatywnym - trudno powiedzieć. Na pewno jest zjawiskiem grupowym, a może i „gatunkowym”, którego nie interesuje człowiek jako osoba.

Nie można bowiem zapominać o tym, że w każdej wypowiedzi przenikają się wymiary - jak to z Ebnerem prowizorycznie nazwaliśmy - kultury i religii, a więc grupy (często $z$ jej negującą osobę ideologią, a na pewno z funkcją społeczna, jak to wynika z tekstów Bourdieu) i osoby (przezwyciężającej ideologię w aktualności słowa). Wiąże się to z faktem, że obok tego, że jestem „Ja” (osobą), pełnię także rolę społeczną, z odpowiadającym tej roli autorytetem i działaniami do wykonania.

Także i to drugie słowo ma jednak swoistą moc, pochodzącą według Bourdieu od grupy, jednak niekoniecznie wykorzystywaną w sensie wspominanym przez Ebnera. Pasjonującym - jednak przekraczającym ramy niniejszego artykułu - zadaniem byłaby próba połączenia obu wymiarów (Ebner próbuje tego, wychodząc od perspektywy rozwoju życia jako takiego). Spróbujmy jednak przynajmniej podsumować poszukiwania źródeł sprawczej mocy słowa.

Moc ta pochodzi na pierwszy rzut oka od samego języka, funkcjonujących w nim konstrukcji, używanych słów i stworzonego dla nich kontekstu, 
aby mogły być performatywne. Aby jednak pytać dalej, musimy wyjść poza lingwistykę w sensie ścisłym. Wydaje się bowiem, że źródło mocy słowa leży w jego aktualności, aktualności rozumianej szeroko, na sposób Ebnera, a więc nie tylko po prostu aktu mowy (Austin), czy też aktualnego dyskursu (Benveniste). Muszą być przy tym więc spełnione wymienione warunki. Właściwie są to warunki aktualności słowa u Ebnera, wzbogacone o punkty widzenia pozostałych myślicieli. Przede wszystkim warto pamiętać, że - jak twierdzi Austin, a wcześniej Ebner - właściwie każda wypowiedź nie tylko stwierdza coś, lecz jest pewnym działaniem. Nie zapominajmy też, że podstawowym działaniem słowa jest „,generowanie” subiektywności: jak wskazuje Benveniste, a wcześniej Ebner, język zbudowany jest właśnie tak, że w mowie wyraża się podmiot, „ten jest Ja, kto mówi Ja” - odnosząc się do tego, co wypowiada. Możemy to podsumować na sposób Ebnera, że chodzi o „udostępnienie realnego Ja realnemu Ty”, o przejście na poziom osobowy, czyli o „zagadnięcie Ty”, ale takie, które nie czyni z niego podmiotu ideologii, lecz buduje relację międzyosobową. Słowo aktualne, co więcej - aktualne osobowo, dysponuje mocą „dotknięcia” innego człowieka, budzenia w nim życia duchowego, wprowadzania go w relację z Drugim, a przez to z Bogiem.

Dalszym krokiem jest pytanie o pochodzenie mowy. „Człowiek ma słowo" - oto podstawowe stwierdzenie antropologii Ebnera - słowo ma on jednak od Boga i po to, by nawiązać stosunek do Boga w człowieku. A przez to prowadzić dalej ewolucję życia, wprowadzić ją na poziom duchowy.

$\mathrm{Na}$ innym biegunie stoją wypowiedzi Bourdieu, który - oczywiście w kontekście socjologicznym - widzi moc słowa w delegacji otrzymanej od grupy. „Performatywne lub też magiczne działanie instytucjonalnych aktów ustanowienia leży nie w samym języku, lecz ugruntowane jest przez pozajęzykową instytucję" "48. Rozważania Bourdieu poruszają się jednak w zupełnie innym kontekście. Tutaj tematem jest, jak opisaliśmy, walka o wprowadzenie własnych klasyfikacji, własnego języka, a przez to o panowanie własnej grupy - a więc aspekt mocy w sensie panowania. Tak jak u Ebnera można mówić o delegacji otrzymanej od Boga, tak u Bourdieu - od grupy społecznej.

Podsumujmy więc spostrzeżenia odnośnie do ,performatywnej” mocy słowa:

48 Gerald Posselt, „Repräsentation und Performativität. Sprechakttheoretische Überlegungen im Anschluss an Austin, Benveniste, Bourdieu und Derrida”, w: Ereignis Denken, TheatRealität - Performanz - Ereignis, red. Arno Böhler (Wien: Passagen, 2009), 195-218. 
1. Pierwszy problem można by, zależnie od punktu widzenia, nazwać problemem zgodności między osobą a słowem lub też problemem autorytetu. Wypowiadane słowo musi mieć pokrycie w osobowości mówiącego, musi zachodzić zgodność między jego słowem a byciem - i to niezależnie od tego, czy autorytet pochodzi od Boga, czy od grupy. Tu przynależy też problem kłamstwa, być może nieusuwającego całkiem skuteczności słowa, ale szkodzącego mu (przypomnijmy warunki kategorii 5 i 6 u Austina).

2. Słowo mówiącego Ja musi dosięgnąć Ty (por. także Bourdieu). A więc Ty musi zostać ,zagadnięte”. Odnośnie do tegoż istnieją jednak różne koncepcje, widzące $\mathrm{w}$ takim zagadnięciu zbawienie dla „Ja” albo chęć jego zniszczenia. Prawdziwa skuteczność - przyjmijmy tu z Ebnerem, nie wydarza się wtedy, gdy indywiduum zostaje zagadnięte przez ideologię, przez aparat ideologiczny (Althusser). Może być przecież tak, że czuję się zagadnięty, ale tym samym zniewolony, zagrożony, poniżony. Jest tak, gdy zostaję uczyniony Ty Ja ideologicznego i czuję tego skutki. Według Ebnera, jest to nadużycie słowa. Prawdziwa skuteczność ma miejsce wtedy, gdy realnemu Ty zostaje udostępnione Ja, a więc zaczyna się relacja międzyosobowa. Na dłuższą metę dopiero wtedy tak naprawdę ,jestem”, „żyję".

3. Słowo ma swoją specyfikę, nie da się bez (negatywnych) konsekwencji używać instrumentalnie, według mojej samowoli. Przeznaczeniem słowa jest ,zbudowanie” drugiego człowieka (dlatego Ebner używa ewangelicznego słowa „miłość” jako niejako „drugiej strony słowa”, nie jego ucisk czy zniewolenie. Inne użycie słowa niż wskazuje na to jego specyfika zwraca się nie tylko przeciw ,zagadniętemu", lecz także mówiącemu, i w ogóle społeczeństwu. Słowo jest niejako sposobem prowadzenia dalej ewolucji życia: każde „złe" użycie słowa podminowuje zaufanie, potrzebne do budowy relacji; każde „dobre” użycie słowa jest jednocześnie nawiązaniem relacji z jego źródłem (Bogiem - wg Ebnera), dopiero wtedy jest ono autentyczne i uwalnia człowieka. Jest ono staraniem się o wejście w sytuację ,bycia uprawnionym” do wypowiadania danego słowa, walką o ,autorytet”.

4. Droga przez kulturę i droga przez osobistą relację: obie mogą pod pewnymi warunkami prowadzić do „sukcesu” - jakim jest zbudowanie relacji międzyosobowej.

a. Droga przez osobistą relację opiera się pierwotnie na aktualności osobowej słowa: udostępnieniu realnego Ja realnemu Ty. Tu 
jednak nie można zapomnieć, że także w osobistej relacji trwają dalej elementy kultury, pomagając w niej lub przeszkadzając. A więc i tu możemy mówić o aktualności rzeczowej. Zaprzeczanie temu może być - paradoksalnie - elementem walki ideologicznej. Istnieje jednak szansa dojścia do Boga także poprzez tę aktualność rzeczową, na zasadzie: jeśli coś jest prawdą (dodajmy: braną w miłości), to jest to coś Boskiego, bo Prawdą jest przecież sam Bóg. Inaczej mówiąc, gdy mamy aktualność rzeczową, to większa jest możliwość osiagięcia także osobowej.

b. Droga przez kulturę - a więc przez aktualność rzeczową - opiera się najpierw na osobistej relacji między autorem a „źródłem słowa" (można by nieco upraszczając powiedzieć: Bogiem) źródłem leżącym w absolutnej zgodności słowa z byciem. Relacji z odbiorcą (aktualności osobowej) jeszcze nie ma, ale zrodzone ze źródła słowo zostaje niejako „powierzone” kulturze. Relacja z potencjalnym odbiorcą jest więc „pośrednia” - poprzez kulturę. Aby słowo stało się naprawdę skuteczne, musi być przez odbiorcę przyjęte w swej aktualności osobowej, jako adresowane do niego osobiście.

\section{Konkretne wnioski}

Co oznacza moc słowa w kontekście pedagogiki i medycyny? Warto uświadomić sobie - instynktownie zapewne - i tak obecną sprawę, że nasze słowa mają moc. Prowadzi to do bardzo praktycznych wniosków:

Wiedząc o mocy słowa, staję się świadomy, że wypowiadanie się, udzielanie informacji, a tym bardziej wskazówek, napomnień itd. nie jest nigdy prostym stwierdzaniem faktu. „Ma pan raka płuc”, „Pana dziecko jest nadpobudliwe" - to niewątpliwie wypowiedzi, które są zarazem działaniami, które coś powodują u słuchającego. Dzieje się tak jednocześnie na dwóch płaszczyznach: są to z jednej strony wypowiedzi instytucji, która mówi ustami lekarza czy nauczyciela będącego jej subiektem. Z drugiej strony jest to wypowiedź człowieka do człowieka: jeśli widzę mojego interlokutora jako osobę, to buduję relację Ja-Ty i będę starał się go „podbudować”, jakoś mu pomóc.

Wiąże się to oczywiście ze stwierdzeniem, że wypowiedzi można używać (niekoniecznie w sposób zamierzony) do tego, by drugiego podbudować albo poniżyć. To wydarza się zawsze: albo jedno, albo drugie. Pierwsza 
sytuacja zaistnieje, gdy dokona się spotkanie dialogiczne, gdy Ja (osobiste) zostanie udostępnione Ty. Chodzi więc o spotkanie możliwe dzięki opisanym warunkom, nie o mierzenie sił, podporządkowanie sobie drugiego. Druga sytuacja pojawia się, gdy nad osobowością dominuje ideologia lub chociażby funkcja społeczna (z jej autorytetem). Tu dominuje aspekt „mocy” w sensie ,przemocy”. Obu sytuacji nie uda się zapewne rozdzielić, choćby dlatego, że do spotkań międzyludzkich dochodzi przeważnie na podstawie funkcji społecznej. Na przykład: rodzic posyła dziecko do szkoły nie dlatego, że jest tam wspaniała pani Asia, ale dlatego, że szkoła jest instytucją edukacyjną. Nauczyciel nie uwolni się od swej funkcji, ale może w jej ramach postrzegać rozmówcę jako osobę lub nie. Tak samo lekarz: także i do niego ludzie przychodzą w pierwszym rzędzie dlatego, że jest lekarzem. Można by tu jeszcze raz nawiązać do aktualności rzeczowej w sensie: „to, co mówię, jest prawda", a więc kompetencji zawodowych, zaufania do instytucji. Jest jednak radykalna różnica między obecnością aspektu osobowego i jego brakiem. Zaniedbywanie aktualności osobowej i ograniczenie się do rzeczowej neguje w końcu także tę drugą.

Tak więc nie uda się zniwelować funkcji, by stać się jedynie osobą i nie trzeba tego robić. Byłoby to nawet niekorzystne, bo ludzie na to właśnie liczą. Bourdieu pokazuje szczególnie mocno, że do skuteczności czynności potrzeba także zewnętrznych czynników: biały fartuch, dziennik w rękach nauczyciela, pomieszczenia itd. Jeśli jednak przy tym pozostaniemy, nie osiagniemy tego, czego tak naprawdę chcemy. To wszystko jest potrzebne po to, aby działanie uzyskało swą performatywną moc, a nie samo dla siebie.

Dialogiczność - którą chcemy uwzględnić także w kontaktach instytucjonalnych - zakłada, że jedna ze stron przejmuje inicjatywę, staje się aktywna, przechodzi na poziom osobowy. $Z$ reguły dialog może zacząć tylko strona „mocniejsza” z punktu widzenia siły, to znaczy w tym przypadku lekarz lub nauczyciel. Mają oni tę siłę na zasadzie autorytetu. Oni są więc niejako odpowiedzialni za przejście granicy instytucja/osoba. Oczywiście w konkretnej sytuacji może to wyglądać różnie, lekarz może na przykład porzucić swą funkcję (przejść granicę), ale po to, by domagać się łapówki.

Należy pamiętać bowiem, że nie każde nawiązanie kontaktu jest wezwaniem do dialogu. Nieraz dochodzi do tego, że w imię dialogu należy milczeć. Udawanie, że jestem w dialogu, mówienie tak, jakbym w nim był, podczas gdy poddaję się jedynie ideologii - to nic innego jak pustosłowie. Mowa dialogiczna (tzn. adresowana po linii Ja-Ty, udostępniająca jedno drugiemu) nie równa się mowie funkcjonalnej (między funkcjami społecznymi, między procedurami), która wypowiada formuły dokonujące działania, a więc per- 
formatywne („Pacjent zostaje wypisany do domu”, ,student zaliczył przedmiot” i ,zdał do następnej klasy”, ale także np. „dziecko jest nadpobudliwe”, „pacjent musi brać taki a taki lek”). Ostatecznie jest to sprawa osobistego wyczucia: na ile jestem urzędnikiem a na ile człowiekiem. Ale - pytanie chyba retoryczne - czy warto dobrowolnie pozbawiać się człowieczeństwa?

\section{The Topicality and Performativity of the Word (Summary)}

The recent popularity of words like "performative" or "performance" expresses as an obvious thing that the human word does not only describe something, but it also performs something. In this article, the issue of the power of the spoken language will be analyzed in view of the concepts of such thinkers as Ferdinand Ebner, John L. Austin, Emile Benveniste, and Pierre Bourdieu. At first, following Ebner's line, it is analyzed the personal and factual "actuality" of the word, and how the "actual word" gets its power of acting. Ebner distinguishes here between a maieutic and a generative power. His ideas get subsequently confronted with the thought of Austin and his concepts of a constative and performative utterance. Then Benveniste's idea of "performativity" and Bourdieu's one of "social magic" are presented. It is interesting how Ebner's dialogical thinking widens the modern linguistic and sociologist concepts. According to the analysis of the thoughts coming from such different disciplines and different ways of thinking it is tried to work out the concrete suggestions, significant also for pedagogics. In short, the teacher's word, to have power, needs a specific balance between dialogic attitude and authority coming from the teacher's social function.

Key words: performance; performative utterance; constative utterance; philosophy of dialogue; Ferdinand Ebner; John L. Austin; Emile Benveniste; Pierre Bourdieu.

\section{Aktualność i performatywność słowa (Streszczenie)}

Popularne ostatnio słowa „performatywny” czy performance wyrażaja jako rzecz oczywista, że ludzkie słowo nie tylko coś wypowiada, lecz także czegoś dokonuje. W niniejszym artykule problematyka mocy języka mówionego zostaje przeanalizowana na podstawie koncepcji takich myślicieli, jak: Ferdinand Ebner, 
John L. Austin, Emile Benveniste i Pierre Bourdieu. Na początku analizowana jest wraz z Ebnerem osobowa i rzeczowa ,aktualność słowa” oraz w jaki sposób słowo aktualne uzyskuje moc sprawcza, określaną jako maieutyczna lub generatywna. Następnie koncepcja ta zestawiona zostaje z rozważaniami Austina i jego znanym podziałem na wypowiedzi „konstatywne i performatywne”. Kolejnym myślicielem jest Benveniste i jego koncepcja performatywności oraz Pierre Bourdieu i to, co nazywa on „magią społeczną”, ujawniającą się przy badaniu takich zjawisk jak ,akty mianowania” (rites d'institution) i ,walki o klasyfikację". Jest rzeczą zdumiewająca, jak bardzo dialogiczne myślenie Ebnera poszerza współczesne koncepcje lingwistyczne i socjologiczne w tej dziedzinie. $Z$ tego zestawienia myśli wywodzących się z tak różnych dziedzin i różnych sposobów myślenia zostają następnie wyciagnięte konkretne wnioski, także dla działań pedagogicznych. Krótko mówiąc: aby słowo pedagoga miało moc, potrzebna jest swoista równowaga między dialogicznością a autorytetem jego funkcji społecznej.

Słowa kluczowe: performatywność; aktualność słowa; filozofia dialogu; Ferdinand Ebner; John L. Austin; Emile Benveniste; Pierre Bourdieu.

\section{Bibliografia}

Austin, John L. „Performatif: constatif”. W: La Philosophie analytique, 271-281. Paris: Editions de Minuit, 1962.

Austin, John L. Zur Theorie der Sprachakte. How to do things mit words, thum. Elke von Savigny. Stuttgart: Reclam, 1972.

Benveniste, Emile. Probleme der allgemeinen Sprachwissenschaft, thum. Wilhelm Bolle. München: List, 1974.

Bourdieu, Pierre. Was heißt Sprechen? zur Ökonomie des sprachlichen Tausches, thum. Hella Beister. Wien: Braumüller, 2005.

Ebner, Ferdinand. „Versuch eines Ausblicks in die Zukunft”. W: Ferdinand Ebner, Schriften, t. 1, red. Franz Seyr, 719-908. München: Kösel, 1963.

Ebner, Ferdinand. „Notizen“. W: Ferdinand Ebner, Schriften, t. 2, red. Franz Seyr, 9-550. München: Kösel, 1963.

Ebner, Ferdinand. „Die Wirklichkeit Christi”. W: Ferdinand Ebner, Schriften, t. 1, red. Franz Seyr, 522-573. München: Kösel, 1963.

Ebner, Ferdinand. „Das Wissen um Gott und der Glaube”. W: Ferdinand Ebner, Schriften, t. 1, red. Franz Seyr, 433-449. München: Kösel, 1963.

Ebner, Ferdinand. Stowo i realności duchowe. Fragmenty pneumatologiczne, thum. Krzysztof Skorulski. Warszawa: IFIS PAN, 2006. 
Ebner, Ferdinand. Ethik und Leben - Fragmente einer Metaphysik der individuellen Existenz, red. Richard Hörmann, Ernst Pavelka. Hamburg u.a.: LIT, 2013.

Ebner, Ferdinand. Wort und Liebe, red. Richard Hörmann, Krzysztof Skorulski. Hamburg u.a.: LIT, 2015.

Horn, Sam. Tongue Fui, Sztuka walki językiem, przeł. Paweł Cichawa. Warszawa: Studio Emka, 1999.

Posselt, Gerald. „Repräsentation und Performativität. Sprechakttheoretische Überlegungen im Anschluss an Austin, Benveniste, Bourdieu und Derrida". W: Ereignis Denken, TheatRealität - Performanz - Ereignis, red. A. Böhler, 195-218. Wien: Passagen, 2009. 